\title{
An Overview of Cold Hardiness in Woody Plants: Seeing the Forest Through the Trees
}

\author{
Michael Wisniewski and Carole Bassett \\ U. S. Department of Agriculture, Agricultural Research Service, Appalachian Fruit Research Station, Kearneysville, \\ WV 25430 \\ Lawrence V. Gusta \\ University of Saskatchewan, Department of Plant Sciences, Saskatoon S7N 5A8 Canada
}

\begin{abstract}
In response to seasonal changes in growing conditions, trees and other perennials have evolved the ability to cold acclimate as well as undergo a period of dormancy. Cold hardiness is a complex trait with several contributing factors. It is also a dynamic process that changes with time. Factors involved include both bark and wood hardiness, onset of dormancy, flower budbreak and freezing tolerance of the buds, root hardiness, the influence of roots on scion growth, the frost hardiness of current year growth versus older growth, the influence of crop load on the induction of frost tolerance, and the effect of cultural practices. The development of cold hardiness in trees can be divided into five categories: the time of induction of cold acclimation, the rate of acclimation, the degree of freezing tolerance attained, the maintenance of freezing tolerance during the winter months, and the rate of loss of freezing tolerance upon resumption of spring growth.
\end{abstract}

There is a wealth of history in the area of frost tolerance of plants that dates back to the 19th century (Burke et al., 1976; Steponkus, 1984). It is fair to say, however, that while many thousands of reports have been published on plant cold hardiness, and perhaps several hundreds of reviews, a complete and integrated understanding of the topic remains elusive. One need only conduct a historical comparison of reviews to see that while perspectives have changed, the overall landscape has remained the same (Artlip and Wisniewski, 2001; Burke et al., 1976; Chen et al., 1995; Sakai and Larcher, 1987; Steponkus, 1984; Thomashow, 1999, 2001; Wisniewski and Arora, 2000; Xin and Browse, 2000).

Early observations of plant cells freezing under a microscope (Molisch, 1897; Wiegand, 1906) led to the understanding that in acclimated plants, ice forms in extracellular spaces resulting in cytorrhysis (the simultaneous contraction of the protoplast and collapse of the cell wall due to loss of water to extracellular ice). Extending these observations, Maximov (1912) suggested that disruption of the plasma membrane was the primary cause of freezing injury. These early studies provided the foundation for research conducted by Jake Levitt and Dave Siminovitch at McGill University, under the direction of the famous botanist, G.W. Scarth. In a series of classic papers published from 1936 to 1941 (Levitt and Scarth, 1936a, 1936b; Levitt and Siminovitch, 1940; Scarth and Levitt, 1937; Siminovitch and Scarth, 1938; Siminovitch and Levitt, 1941), these scientists documented that intracellular freezing was universally lethal to plant cells but did not occur in acclimated plants. They further demonstrated that the permeability of the plasma membrane increased during acclimation and played an important role in preventing intracellular ice formation and that ice-induced cell dehydration could lead to disruption of the plasma membrane upon thawing (Burke and Nozzolillo, 2002). This latter point was perhaps not fully appreciated until the later research published by Jas Singh (a graduate student of D. Siminovitch), Agriculture Canada, and Peter Steponkus at Cornell University (see review by Steponkus, 1984). Later work on the disruption of membrane transport properties as a result of freezing injury by Jiwan Palta, University of Wisconsin, also would build on this seminal work (Palta and Li, 1978and 1980). It is also recognized commonly that the texts by Levitt $(1972,1980)$ are one of the few attempts that have been made to review the literature comprehensively and to present the findings into an integrated view of stress tolerance in plants. The text by Sakai and Larcher (1987) is a more recent attempt to present a comprehensive view of frost tolerance.

E-mail addresses: mwisniew@afrs.ars.usda.gov; cbassett@afrs.ars.usda.gov; gusta@duke.usask.ca.
D. Siminovitch and his graduate student, Keith Pomeroy also were among the first to document that the protoplasm underwent distinct biochemical changes during cold acclimation that presumably played a direct role in conferring stress tolerance (Pomeroy and Siminovitch, 1971). Research by the Russian scientist I. Tumanov (as reviewed in Sakai and Larcher, 1987) also recognized the importance of biochemical changes during cold acclimation. Truly, the research conducted by these pioneers in the first half of the century formed the conceptual basis of much of what was to follow.

Regarding cold hardiness research, it is also important to recognize the important contribution that was made by the Plant Cold Hardiness Laboratory at the University of Minnesota, St. Paul, beginning in the 1960s, under the leadership of Conrad J. Weiser. Research (as reviewed in this article) conducted by scientists and graduate students at this laboratory dominated the literature for over 25 years (1960-85). A greater understanding of deep supercooling, the biophysics of water at low temperatures, dormancy, the role of sugars in cold hardiness, and more, all grew from the activities of this laboratory. People such as Paul Li, Leslie Fuchigami, Harvey Quamme, Lawrence Gusta, Milon George, Michael Burke, Jiwan Palta, John Carter, Cecil Stushnoff, Margaret Smithburg, Tim Hall, Stan Howell, Phil Graham, Robert McLeester, Bob van Huystee, and others were associated with the Plant Cold Hardiness Laboratory and would go on to staff many of the horticulture departments in the U.S. and Canada. The seminal paper by Weiser (1970) often is cited for its recognition that changes in proteins during cold acclimation also implied changes in gene expression. "Bud" Weiser later went on to chair the Department of Horticulture at Oregon State University. In the latter part of the 20th century, characterizing the genetic regulation of cold hardiness has dominated the literature (Thomashow, 1999; Xin and Browse, 2000).

Strategies allowing plants to survive freezing temperatures have been organized into two categories (Levitt 1980): 1) freezing tolerance and 2) freezing avoidance. Mechanisms representing both categories are common in woody plants (Burke and Stushnoff 1979). In comparison to herbaceous plants, woody species are extremely freezing tolerant. Many species native to boreal forests tolerate $-40{ }^{\circ} \mathrm{C}$ and some can even tolerate $-196^{\circ} \mathrm{C}$ in midwinter. In contrast, very few herbaceous plants tolerate temperatures less than $-25^{\circ} \mathrm{C}$ or prolonged exposure to $-15^{\circ} \mathrm{C}$ for a period of several weeks, whereas certain woody species can tolerate $-40{ }^{\circ} \mathrm{C}$ for months.

In addition to a historical review, the present contribution will cover the main factors involved in woody plant cold hardiness, although reference will also be made to herbaceous plants where applicable. This is especially true for recent advances in the molecular biology of cold acclimation where research with Arabidopsis and other herbaceous crop species has dominated the literature.

\section{ICE NUCLEATION AND PROPAGATION}

Ice nucleation must first occur for ice to form on or within a plant. While this may seem like a simple matter, in fact it is quite complex, and a great deal of research has been conducted on the role of intrinsic and extrinsic ice nucleators in inducing plants to freeze. The ability to supercool tissues several degrees below zero is a form of freezing avoidance. An excellent and very comprehensive review of this topic has been presented by Lee et al. (1995). The role of ice nucleators in inducing ice formation in plants is important because if methods can be developed for regulating ice nucleation, significant advances could 
be made in limiting frost injury to both freezing-sensitive plants and flowers of many fruit crops.

Beginning in the late 1970 s, a considerable amount of research focused on the role of ice nucleating agents in inducing plants to freeze at warm subzero temperatures. Much of this research was conducted by Steve Lindow at the Univ. California, Berkeley, and Edward Ashworth, USDA-ARS (now at Purdue University), and is reported in their seminal papers (see reviews by: Lindow, 1995; and Ashworth and Kieft, 1995). The working hypothesis was that by controlling extrinsic nucleation events, plants could supercool well below $0{ }^{\circ} \mathrm{C}$ and thus avoid freezing (Lindow, 1995). It was felt that such a strategy could provide a significant level of frost protection to frost sensitive plants or plant parts. In fact, the first environmental release of a genetically modified organism for use in agriculture was a strain of ice-nucleating active (INA) bacteria (Pseudomonas syringae) in which a large portion of the gene coding for the nucleation protein was deleted, thus rendering a nonfunctional protein and a phenotype in which ice nucleation activity was absent. This approach was perceived as very controversial by the general public and issues regarding its use filled the headlines of many major newspapers in the early 1980s. In fact, due to regulatory and legal battles, 5 years elapsed between the filing of the permit request and the actual field test (see Lindow, 1995). Society is still wrestling with the application of genetic engineering to production agriculture.

While the majority of reports dealt with the role of ice-nucleatingactive (INA) bacteria, related research focused on the role of other extrinsic nucleating agents and whether or not plants could actually supercool to temperatures several degrees below $0{ }^{\circ} \mathrm{C}$ (Ashworth, 1992). Intrinsic nucleators that are active at warm subzero temperatures have been documented, especially in woody plants (Ashworth and Kieft, 1995). The presence of these internal nucleators limit the ability of a plant to significantly supercool below $0{ }^{\circ} \mathrm{C}$ even in the absence of extrinsic nucleating agents. The identification of a wide range of both extrinsic and intrinsic ice nucleating agents has made complex the practical application of blocking extrinsic ice nucleation.

Recently, infrared video thermography has been used to directly observe ice nucleation (i.e., initial ice formation) and propagation in plants (Ball et al., 2002; Carter et al., 2001, 1999; Fuller and Wisniewski, 1998; Pearce and Fuller, 2001; Wisniewski et al., 1997; Wisniewski and Fuller, 1999; Workmaster et al., 1999). This technology offers distinct advantages over the use of thermocouples to measure plant temperature. The temperature and spatial resolution of the devices used in these studies have enabled researchers to clearly define the initial site of ice nucleation and monitor the ice front as it spread into the surrounding tissues. Using infrared thermography, it is possible to determine the role of extrinsic and intrinsic ice nucleating agents in the freezing process, rates of ice propagation, the effect of plant structure on the freezing process, and how the specific pattern of freezing relates to visual patterns of injury

Wisniewski et al. (1997) demonstrated that the freezing of water droplets on the surface of plants occurs as independent events, and that droplets containing INA bacteria freeze at warmer temperatures than plain water alone. The presence of these droplets could induce open flowers of peach (Prunus persica) and apple (Malus domestica) to freeze. However, intrinsic nucleators that were active at warm subzero temperatures, were also documented in these plants. In most cases, ice was initiated in the outer bark of stem tissues and then propagated into expanded primary tissues, such as flower buds or young shoots, despite the fact that these latter organs were supercooled to lower temperatures (due to radiative cooling) than the stem tissues themselves.

Detailed infrared studies of ice nucleation and propagation have been conducted in cranberry (Vaccinium macrocarpon Ait.) uprights and fruit (Workmaster et al., 1999) and flowering shoots of blackcurrant (Carter et al., 1999, 2001). Ball et al. (2002) provided a comprehensive report of the freezing process in attached leaves of snow gum (Eucalyptus pauciflora Sieb. ex Spreng.) in which they demonstrated that spatial variation in the physical properties of the leaves could affect the distribution of minimum leaf temperatures and hence, the distribution and extent of injury.

Collectively, the above-mentioned studies indicate that barriers to ice nucleation and propagation exist in plants and that plant structure can play an important role in frost resistance (Wisniewski et al., 2002b).
Furthermore, they indicate that the creation and/or enhancement of barriers could be used to improve frost protection. Such an approach could involve both breeding to enhance specific anatomical or structural traits, or the physical application of materials that provide a barrier to ice nucleation. The latter approach recently has been explored in herbaceous plants (Wisniewski et al., 2002a) when a hydrophobic particle film was applied to tomato (Lycopersicon esculentum L.) plants before the application of water containing ice-nucleation-active bacteria. In an environmental chamber, noncoated plants froze at approximately $-2.5^{\circ} \mathrm{C}$, while coated plants supercooled to temperatures as low as $-6.0^{\circ} \mathrm{C}$. The use of this technology to protect flowering shoots of fruit trees or other woody plants, however, may be limited due to the presence of intrinsic nucleating agents. Infrared thermography has also been shown to be useful in studying freezing events in conifers (Sutinen et al., 2001)

\section{DEEP SUPERCOOLING AND GLASS FORMATION}

Deep supercooling, another avoidance mechanism, can be defined as the ability of a population of cells or entire organs to retain cellular water in a liquid phase at low, subfreezing temperatures by remaining free from internal, heterogeneous ice nuclei and isolated from the nucleating effect of extracellular ice (Burke and Stushnoff, 1979). Deep supercooling of flower buds and xylem tissues has been reviewed by several authors (Ashworth, 1992, 1996; Fujikawa and Kuroda, 2000, Quamme, 1995; Quamme et al., 1995; Wisniewski, 1995; Wisniewski and Arora, 1993, 2000; Wisniewski and Fuller, 1999). Supercooling of floral buds stands in contrast to extraorgan freezing where water migrates to sites of extracellular ice away from the bud primordia (Sakai and Larcher, 1987) and equilibrium freezing in bark and xylem tissues where cells lose water to ice crystals present in the surrounding extracellular space (Chen et al., 1995). In both of the latter cases, the amount of water that is lost from a cell is directly dependent on the vapor pressure (and hence temperature) of the ice in the surrounding tissue. The lower the temperature, the more cellular water that is displaced. As a result, the concentration of solutes present in the cell increases and the freezing point decreases. In the present review, only deep supercooling of xylem tissues will be discussed and the reader is referred to other reviews for details on deep supercooling of floral buds vs. extraorgan freezing.

Of the many aspects of plant cold hardiness, deep supercooling is perhaps the most enigmatic (Wisniewski and Arora, 2000). The ability of some plants to maintain symplastic water in an unfrozen condition and without movement of the water into the apoplast is a remarkable adaptation that has not failed to impress both biophysicists and plant physiologists. Wiegand (1906) observed, in trees, deep supercooling down to $-26^{\circ} \mathrm{C}$, and Scarth and Levitt (1937) postulated that in order for supercooling to occur in plants, the liquid mass had to be broken up into droplets or capillary columns and the resulting units or cells needed to be separated by ice-proof barriers to prevent the spread of ice crystallization from its origin. With the advent of the use of thermocouples (Tumanov and Krasavtsev, 1962; Tumanov et al., 1969), and the development of differential thermal analysis (DTA) (Quamme et al. (1972, 1973), detailed studies on deep supercooling were initiated. The mechanism that allows small domains of water to avoid freezing, despite the presence of extracellular ice, however, remains poorly understood, partly because the properties which allow deep supercooling to occur apparently rely on the structural organization of the tissue or organ. This feature has made it very difficult to manipulate plant material in a way so as to discover the fundamental mechanism and/or properties that allow deep supercooling to occur (Wisniewski, 1995; Quamme, 1995).

Deep supercooling of xylem tissues is a common characteristic of many temperate species of woody plants. DTA revealed freezing events in xylem tissues at very low temperatures $\left(-25\right.$ to $\left.-40{ }^{\circ} \mathrm{C}\right)$ the appearance of which is correlated with tissue death (George and Burke, 1977; Hong and Sucoff, 1980; Quamme et al., 1972). Because of this association, DTA has been used extensively to evaluate the degree of cold hardiness of stem tissues of many important woody species of fruit and landscape plants. It has also been suggested that the northern and elevational limits of native woody plants can be correlated with the ability to deep supercool (George et al., 1974). 
In order for deep supercooling to occur a barrier must exist in xylem tissues that prevents the rapid loss of water to extracellular ice and also prevents the growth of ice crystals into living cells. In this regard, the porosity and/or permeability of the cell wall appears to play an essential role in the regulation of deep supercooling. In a series of papers, Wisniewski and Davis (1989), Wisniewski et al. (1991a, 1991b), demonstrated that the structure and composition of the pit membrane of xylem parenchyma appear to play an important role in regulating the extent of deep supercooling of xylem tissues. The pit membrane is a thin portion of the cell wall that allows for the passage of solutes and other materials, including plasmodesmatal connections, between cells. It is composed mainly of cellulose and pectic materials and unlike secondary wall material is nonlignified for at least two years of development. By chemically or enzymatically altering the compostion of this layer of the cell wall, Wisniewski et al. (1991b) demonstrated that deep supercooling could be eliminated or its extent reduced. The pectic component of the pit membrane appeared to play a particularly key role in regulating its porosity, although a unique arabinogalactanrich glycoprotein was also identified in the amorphous layer subtending the pit membrane (Wisniewski and Davis, 1995). The role of this protein is unknown. Detailed studies using cryomicroscopy conducted by Ristic and Ashworth (1993, 1994), Fujikawa and Kuroda (2000) and Kuroda et al. (2003) also support the importance of cell wall properties in determining the ability of xylem ray parenchyma to lose water when exposed to freezing temperatures.

Important to a discussion on the mechanism of deep supercooling is the rate of water movement from cells to extracellular ice and also the rate of freezing employed during freeze tests. Gusta et al (1983) collected from the field a range of woody species exposed to a 3-week period of temperatures less than $-30^{\circ} \mathrm{C}$. A DTA study on nonthawed samples showed a significant depression of low temperature exotherms (LTE) and in some cases a complete absence of the LTE. These results indicate that LTEs reported in many studies employing a cooling rate of $1{ }^{\circ} \mathrm{C} \cdot \mathrm{h}^{-1}$ or greater may be the result of inadequate time for water in the xylem ray parenchyma cells to migrate to extracellular ice. Many of the early studies on deep supercooling employed a cooling rate of 10 to $40{ }^{\circ} \mathrm{C} \cdot \mathrm{h}^{-1}$. These rates would not allow for the water potential of the cell to come into equilibrium with the vapor pressure of the ice.

Another unique response of woody plant cells to freezing temperatures is the ability to form glassed cell solutions (Chen et al., 1995; Hirsh et al., 1985). Glass formation is thought to be a natural adaptation that occurs in extremely hardy plant species that can survive cooling to $-196{ }^{\circ} \mathrm{C}$ in liquid nitrogen. The formation of glasses is a unique metastable condition that cannot be terminated below the glass transition temperature. Aqueous glasses are extremely viscous, brought about by a high solute (sugar) concentration at a sufficiently low temperature. In poplar (Populus tremuloides), glasses can form below $-20{ }^{\circ} \mathrm{C}$ (Hirsh et al., 1985). Although glassed solutions are extremely metastable and exhibit a high degree of supercooling and high hydrostatic tension, they are not subject to ice nucleation, solute crystallization, or water vapor cavitation so long as the solution remains below the melting temperature of the glass. Thus the cytoplasm and its contents are extremely stable and relatively unaffected by the stresses associated with low temperature and the presence of ice. The glassed state is frequently relied upon for the survival of plant tissues during cryopreservation (Steponkus et al., 1992). Slow desiccation and the formation of glasses under natural conditions may be a common response in woody plant species that experience long periods of extremely low temperatures in the range of -30 to $-40{ }^{\circ} \mathrm{C}$.

\section{PHYSIOLOGY AND GENETIC REGULATION OF COLD ACCLIMATION}

Generally speaking, the major stress experienced by frozen cells is believed to be the severe dehydration and concomitant cellular changes (membrane folding, protein denaturation, increased levels of toxic solutes, etc.) resulting from cell water potential coming into equilibrium with the vapor pressure of extracellular ice. The process by which plants actively undergo changes in gene expression and biochemistry that enhance their ability to withstand low temperature and desiccation stress is referred to as cold acclimation. Cold acclimation is a two or three stage process in woody plants (Weiser, 1970), beginning in the first stage with the onset of dormancy, triggered by short day photoperiods (Fuchigami et al., 1970; Irving and Lanphear, 1967). Overexpression of a phytochrome gene (PHY A) in hybrid aspen (Populus tremula $\mathrm{X}$ Populus tremuloides) reduced sensitivity to short day photoperiod, prevented leaf abscission, and inhibited cold acclimation. In addition, levels of gibberellic acid (GA) and indole-acetic acid (IAA) did not decrease in response to short day photoperiod. High levels of GA have been shown to delay or inhibit freezing tolerance (Junttila et al., 2002; Weiser, 1970). While the literature is too extensive to review here, upregulation of abscisic (ABA), increases in specific sugars and other compatible solutes, and the production of specific stress-related proteins all have been associated with cold acclimation and increases in cold tolerance (Chen et al., 1995). In particular, the research of Olavi Juntilla (University of Helsinki, Finland) and his colleagues has greatly increased our understanding of the photoperiodic and hormonal regulation of cold hardiness and dormancy in trees (Juntilla et al., 2002).

Considerable progress has been made in the last decade in understanding cold acclimation through the application of molecular biology techniques and the use of Arabidopsis as a model plant system (Browse and Xin, 2001; Guy, 1999; Kaye and Guy, 1995; Shinozaki and Yamaguchi-Shinozaki, 2000; Thomashow, 1998; Xin and Browse, 2000; ). Although we are still far from having a complete understanding of how plants perceive low temperatures and transduce signals that alter gene expression and metabolism, we have greatly increased our knowledge of how plants acclimate to the cold.

While compositional changes in the lipid components of the plasma membrane, as well as its integral proteins, play an important role in the development of freezing tolerance (Lynch and Steponkus, 1987; Palta and Li, 1978, 1980; Siminovitch et al., 1975; Steponkus et al., 1998), they are by no means the only mechanism contributing to cold hardiness. Early work aimed at identifying genes responsive to cold treatment involved global analysis of changes in protein abundance (Guy, 1990). The results of this approach eventually led to the application of molecular biology techniques to isolate individual cold-inducible genes, examples of which are shown in Table 1. Some of these genes are associated primarily with other aspects of cellular metabolism, such as, phosphoenolpyruvate carboxykinase (Saez-Vasquez et al., 1995) and ATPase (Orr et al., 1995). Others are involved with providing protection to the plant from other stresses, like heat-shock (Ukaji at al., 1999), reactive oxygen intermediates (Llorente et al., 2002; Seppanen et al., 2000) and pathogen attack (Yeh et al., 2000).

Cold-responsive genes likely to be involved with development of cold tolerance include those encoding enzymes responsible for the synthesis of sugars or sugar derivatives (Dejardin et al., 1999; Guy et al., 1992; Taji et al., 2002) and compatible solutes or proteins (Newton and Duman, 2000; Xing and Rajashekar, 2001). Still others appear to be associated with the dehydrative aspects of freezing stress. For example, one of the largest groups of genes associated with cold response is one encoding late embryo-abundant (LEA and LEA-like) proteins (Close, 1997). Some of these proteins have been shown to have antifreeze or cryoprotective properties, but the mechanism through which they provide such protection is unknown. These genes, and in some cases their cognate proteins, also have been shown to be seasonally expressed or cold-inducible in woody plant species (Arora et al., 1992; Arora and Wisniewski, 1994; Artlip et al., 1997; Muthalif and Rowland, 1994; Rinne et al., 1998, 1999; Sarnighausen et al., 2002; Welling et al., 1997).

Another large group of cold-responsive genes are the COR (cold responsive) genes [i.e., cold-induced $(K I N)$, low temperature inducible $(L T I)$, responsive to dehydration $(R D)]$. Although these genes are associated with the plant's response to cold, except for COR15a (Steponkus et al., 1998) their role in the development of cold acclimation is not clear. One reason is that overexpression of these genes does not enhance freezing tolerance at the whole plant level (Kaye et al., 1998). On the other hand, given the complexity of cold acclimation, overexpression of a single cold-responsive gene may not reflect a realistic physiological condition that can lead to whole plant cold tolerance. Reverse genetics (i.e., knockout by antisense or transposon tagging) of these genes may present a clearer picture of their role in freezing tolerance.

One of the most important questions in understanding the 
Table 1. Genes associated with cold tolerance.

\begin{tabular}{|c|c|c|c|}
\hline $\begin{array}{l}\text { Specific gene or } \\
\text { protein class }\end{array}$ & Organism & $\begin{array}{l}\text { Function or } \\
\text { identity }\end{array}$ & References \\
\hline \multirow[t]{4}{*}{$\overline{\mathrm{COR} / \mathrm{KIN} / \mathrm{LTI} / \mathrm{CAS}}$} & Arabidopsis thaliana & Not known at present & $\begin{array}{l}\text { Kurkela and Franck 1990; Gilmore et al., 1992; } \\
\text { Horvath et al., 1993; Welin et al., } 1994\end{array}$ \\
\hline & Brassica napus & & Weretilnyk et al., 1993; Orr et al., 1992 \\
\hline & Spinacia oleracea & & Kaye et al., 1998 \\
\hline & Medicago spp & & Monroy et al., 1993; Luo et al., 1991 \\
\hline \multirow[t]{6}{*}{ LEA or LEA-like } & Arabidopsis thaliana & Interact with other proteins? & Choi et al., 1999 \\
\hline & Triticum aestivum & & Tsuda et al., 2000; Ndong et al., 2002 \\
\hline & Poncirus trifoliata & & Cai et al., 1995 \\
\hline & Prunus persica & & Artlip et al., 1997 \\
\hline & Morus bombycis & & Ukaji et al., 2001 \\
\hline & Vaccinium corymbosum & & Levi et al., 1999 \\
\hline cor tmc-ap3 & Hordeum vulgare & $\begin{array}{l}\text { Chloroplastic amino acid selective } \\
\text { channel protein }\end{array}$ & Baldi et al., 1999 \\
\hline Glycine-rich proteins & Medicago falcata & Not known at present & Luo et al., 1992; Laberge et al., 1993 \\
\hline Protein kinases & $\begin{array}{l}\text { Arabidopsis thaliana } \\
\text { Triticum aestivum }\end{array}$ & Associated with signal transduction & $\begin{array}{l}\text { Hong et al., } 1997 \\
\text { Holappa and Walker-Simmons } 1995\end{array}$ \\
\hline Metabolic enzymes & Brassica napus & $\begin{array}{l}\text { PEP carboxykinase } \\
\text { Enolase }\end{array}$ & $\begin{array}{l}\text { Saez-Vasquez et al., } 1995 \\
\text { Lee et al., } 2002\end{array}$ \\
\hline \multirow{6}{*}{$\begin{array}{l}\text { Osmotin-like gene } \\
\text { blt4.9 } \\
\text { blt14 } \\
\text { blt101, RC12a \& b } \\
\text { Defense proteins }\end{array}$} & Solanum dulcamara & Osmotin-like protein & Newton and Duman, 2000 \\
\hline & Hordeum vulgare & Lipid transfer protein? & Dunn et al., 1991 \\
\hline & & Not known at present & Dunn et al., 1990 \\
\hline & & Not known at present & Goddard et al., 1993; Capel et al., 1997 \\
\hline & Solanum commersonii & Glutathione S-transferase & Seppanen et al., 2000 \\
\hline & Arabidopsis thaliana & Peroxidase & Llorente et al., 2002 \\
\hline
\end{tabular}

mechanism(s) of cold acclimation is the identity of the components in pathways transducing signals in response to perception of low temperature (Knight and Knight, 2001; Xiong et al., 2002b). Research in the last decade has suggested that at least one component of cold acclimation works through a mitogen-activated protein kinase (MAPK) pathway (Jonak et al., 1996; Sangwan and Dhindsa, 2002) consisting of a cascade of protein kinases that activate each other in a step-wise fashion. MAPK cascades are universal signal transduction pathways found in all organisms, and it has been shown that multiple MAPK pathways within a cell are differentially activated by a variety of external stimuli and/or stresses (Agrawal et al., 2003 and others). There is also evidence of several intracellular triggers that activate the MAPK cascade during cold acclimation. One of these involves calcium signaling (Monroy and Dhindsa, 1995), while another implicates cyclic ADP-ribose (cADP) as an internal signal (Wu et al., 1997). cADP is thought to be a primary response to ABA signaling and therefore may stimulate the ABA-dependent pathway leading to cold acclimation (Xin and Browse, 2000). Recent work in this area also suggests that calcium-stimulated activation of phospholipases $C$ and D is an early response to cold adaptation (Ruelland et al., 2002). These enzymes create phosphorylated derivatives of inisitol which, like cADP and calcium, can act as intracellular messengers. Such studies also emphasize cross-talk among various cellular pathways leading to levels of complexity that are probably necessary for flexibility in the cell's ability to respond to multiple signals simultaneously, but hinder research progress in this area. Finally, since protein kinases represent only half of the phosphate signaling mechanism, protein phosphatases, which activate or deactivate proteins by dephosphorylation, also should be associated with cold responsiveness. Indeed, Meskiene et al. (1998) have isolated a protein phosphatase $2 \mathrm{C}$, which inactivates the stressactivated MAPK cascade of Jonak et al. (1996) and may serve to reset the system in preparation for the next signaling event.

\section{MOLECULAR GENETICS OF COLD ACCLIMATION}

One approach to isolating genes associated with complex traits like cold acclimation is to use molecular mapping techniques (e.g., random amplification of polymorphic DNA [RAPD] or single nucleotide polymorphism [SNP]) to saturate chromosomes with markers and facilitate the identification of traits cosegregating with them. These techniques have been successfully used in plants with extensive genetics, like maize, but have proven more difficult to use with polyploid or slow-breeding species such as woody plants (Arora et al., 2000; Bliss et al., 2002). Nevertheless, several laboratories have begun using these approaches with a variety of crop species, such as citrus (Cai et al., 1994), and rice (Kim et al., 2000).

Another productive approach to understanding the contribution of specific genes to the development of cold hardiness is to isolate mutants in response to cold treatment. This approach highlights the benefits of using Arabidopsis as a model, since a number of important genes significant to the development of cold tolerance have been identified in this organism. For example, Knight et al. (1999) have characterized a mutant allele, sfr6, in Arabidopsis that suppresses cold-induction of CRT/DRE-containing genes. Another genetic locus, HOS1, encodes a RING finger protein that locates to the nucleus upon cold treatment and suppresses transcription of a number of genes, including those regulated by CRT/DRE elements (Lee et al., 2001). Xin and Browse (1998) isolated a proline-accumulating mutant called eskimo1 which conferred some $\left(\approx 2{ }^{\circ} \mathrm{C}\right)$ freezing tolerance to nonacclimated plants, suggesting that the gene represses cold acclimation in its wild type state. More recently a mutation conferring freezing sensitivity, frs 1 , has been shown to represent a new ABA3 allele (aba3-3) and is believed to be a defect in the last stage of ABA synthesis (Llorente et al., 2000). This result supports previous observations suggesting an overlap in cold- and water deficit-sensing pathways.

\section{REGULATION OF GENE EXPRESSION IN RESPONSE TO COLD}

How are cold-responsive genes regulated? One way to control gene expression is to alter the rate of transcript initiation by influencing the activity of RNA polymerase II (RNA polII). Recognition of individual genes in response to specific stimuli or in specific organs/tissues is conferred by the interaction of various transcription factors (TFs) that bind to defined sequences in the promoter regions of the target genes and interact with RNA polII to enhance or suppress transcript initiation. Early studies of cold responsive genes, such as COR15, identified cisacting elements which were specific for cold or dehydration responses. These DNA sequences, called C-repeat (Baker et al., 1994) or DREB (Yamaguchi-Shinozaki and Shinozaki, 1994) elements, contain a core sequence consisting of CGAC. In subsequent studies the TFs binding to these elements were identified and characterized (Thomashow, 1999). In this way a family of AP2-domain C-repeat binding factors (CBFs) was shown to be associated with response to low temperature (Gilmour et al., 1998; Liu et al., 1998), but not ABA (Medina et al., 1999). Since then, other TFs representing different classes have been shown to be associated with cold-responsive gene expression (Lee et al., 2002; Xiong et al., 2002a).

\section{GLOBAL PATTERNS OF GENE EXPRESSION IN}




\section{RESPONSE TO COLD}

As discussed above, cold acclimation is a complex process involving the expression of multiple genes. The development of new techniques has facilitated the identification of large numbers of genes responsive to a variety of stimuli, including cold treatments. For example, expression profiling using microarrays of DNA on filters hybridized with cDNAs derived from tissues after selected treatments has allowed the identification of a number of genes that are up- or down-regulated by cold (Fowler and Thomashow, 2002; Kollipara et al., 2002). In addition, two-dimensional gel electrophoresis of proteins is once again being used to profile the proteome, which is all the polypeptides expressed in a given tissue under a give set of stimuli, and has recently been applied to the response of flax seedlings to cold shock (Tafforeau et al., 2002).

\section{GENETIC ENGINEERING APPROACHES}

In an effort to understand the contribution of various individual genes to the development of cold hardiness, a number of researchers have analyzed overexpression of particular genes to determine the effects on cold responsiveness or cold tolerance. For example, ectopic expression of the seed-specific transcription activator, $\mathrm{ABI} 3$, enhances freezing tolerance in vegetative tissues of Arabidopsis (Tamminen et al., 2001). In addition, overexpression of CBFs upregulates a suite of genes and has been shown to enhance freezing tolerance (Gilmour et al., 2000; Jaglo-Ottosen et al., 1998; Kasuga et al., 1999). An interesting application of this strategy is the ectopic expression of an invertase inhibitor to prevent cold-induced sweetening in potato tubers during storage (Greiner et al., 1999). Antisense inhibition has also been successfully applied to alter cold acclimation. In Arabidopsis antisense inhibition of protein phosphatase $2 \mathrm{C}$ accelerated cold acclimation (Tahtiharju and Palva, 2001). Finally, expression of foreign cryoprotective proteins has also been used successfully to protect against cold extremes (Hightower et al., 1991; Huang et al., 2002), although the protection provided has been modest in most cases.

Application of molecular techniques has been key in our initial understanding of the events involved with the development of cold acclimation in plants. Identification of the proteins involved in signaling cold perception will help researchers understand their contribution to cold acclimation, and unraveling their interactions with other pathways will continue to represent a real challenge. Since transcription factors themselves are prone to activation/deactivation by virtue of their interaction with activators and repressors, identifying proteins that interact with various cold-responsive TFs may facilitate our ability to separate out cold-specific responses from reponses occuring through other pathways, like drought, ABA, and light. This information could enable us to genetically engineer enhanced freezing tolerance without affecting other important defense or developmental processes.

\section{SUMMARY}

The history of plant cold acclimation research is long and extensive. In a review on the role of the plasma membrane in freezing injury and cold acclimation, Steponkus (1984) noted that Roberts and Miska (1980) provided a bibliography on plant cold hardiness that contained 2,900 references published between 1965 to 1975, with an addendum of an additional 743 titles for completeness. Since that time it seems that the number of scientific publications has increased at an exponential rate, as have the technologies for conducting plant research. In regards to the cold acclimation of woody plants, one can ask whether or not we are any closer to understanding cold hardiness in a comprehensive manner. Can we see the forest through the trees?

In the last ten years or so, $\approx 75 \%$ of the research done on plant cold hardiness has been conducted on a weed species, Arabidopsis thaliana, that can only cold acclimate by 5 to $8{ }^{\circ} \mathrm{C}$. This research may pertain only to cold tolerance that allows for brief exposures to episodes of frost experienced by frost-sensitive species. It is highly probable that the mechanisms that allow trees to withstand extremely low subzero temperatures for long periods of time may be completely different. Even with the advent of molecular biology, genomics, proteomics, and metabolomics, considerable emphasis will need to be placed on understanding individual gene function and biochemistry. Great progress has been made in understanding cold acclimation in woody plants and plants in general. As with every new generation, the goal appears to be attainable and just out of reach and as with every past generation, one can only stand in awe of what the future promises.

\section{Literature Cited}

Agrawal, G.K., S.K. Agrawal, J. Shibato, H. Iwahashi, and R. Rakwal. 2003. Novel rice MAP kinases OsMSRMK3 and OsWJUMK1 involved in encountering diverse environmental stresses and developmental regulation. Biochem. Biophys. Res. Commun. 300:775-783.

Arora, R., L.J. Rowland, J.S. Lehman, C-C. Lim, G.R. Panta, and N. Vorsa. 2000 Genetic analysis of freezing tolerance in blueberry (Vaccinium section Cyanococcus). Theor. Appl. Genet. 100:690-696

Arora, R., M.E. Wisniewski, and R. Scorza. 1992. Cold acclimation in genetically related (sibling) deciduous and evergreen peach (Prunus persica [L] Batsch). I. Seasonal changes in cold hardiness and polypeptides of bark and xylem tissues. Plant Physiol. 99:1562-1568.

Arora, R. and M.E. Wisniewski. 1994. Cold acclimation in genetically related (sibling) deciduous and evergreen peach (Prunus persica [L.] Batsch). II. A 60-kilodalton bark protein in cold-acclimated tissues of peach is heat stable and related to the dehydrin family of proteins. Plant Physiol. 105:95-101.

Artlip, A. and M. Wisniewski. 2001. Induction of proteins in response to biotic and abiotic stress, p. 657-679. In: M. Pessarakli (ed.). Handbook of plant physiology, 2nd ed. Marcel Dekker, New York.

Artlip, T.S., A.M. Callahan, C.L.Bassett, and M.E. Wisniewski. 1997. Seasonal expression of a dehydrin gene in sibling deciduous and evergreen genotypes of peach (Prunus persica [L.] Batsch). Plant Mol Biol. 33:61-70.

Ashworth, E.N. 1996. Responses of bark and wood cells to freezing. Adv. Low-temp. Biol. 3:65-106.

Ashworth, E.N. 1992. Formation and spread of ice in plant tissues. Hort. Rev. 13:215-255.

Ashworth, E.N. and T.L. Kieft. 1995. Ice nucleation activity associated with plants and fungi, p. 137-162. In: R.E. Lee, Jr., G.J. Warren, and L.V. Gusta (eds.). Biological ice nucleation and its applications, APS Press, Minneapolis, Minn.

Baker, S.S., K.S. Wilhelm, and M.F. Thomashow. 1994. The 5'-region of Arabidopsis thaliana cor 15 a has cis-acting elements that confer cold-, drought- and ABA-regulated gene expression. Plant Mol. Biol. 24:701-713

Baldi, P., M. Grossi, N. Pecchioni, G. Vale, and L. Cattivelli. 1999. High expression level of a gene coding for a chloroplastic amino acid selective channel protein is correlated to cold acclimation in cereals. Plant Mol. Biol. 41:233-243.

Ball, M.C., J. Wolfe, M. Canny, M. Hoffman, A.B. Nicotra, and D. Hughes. 2002. Space and time dependence of temperature and freezing in evergreen leaves. Functional Plant Biol. 2:1259-1272.

Bliss, F.A., S. Arulsekar, M.R. Foolad, V. Becerra, A.M. Gillen, M.L. Warburton, A.M. Dandekar, G.M. Kocsisne, and K.K. Mydin. 2002. An expanded genetic linkage map of Prunus based on an interspecific cross between almond and peach. Genome 45:520-529.

Browse J. and Z. Xin. 2001. Temperature sensing and cold acclimation. Curr. Opin. Plant Biol. 4:241-246.

Burke, M.J. and C. Nozzolillo. 2002. In memoriam: David Siminovitch (1916-2001). Cryobiology 44:1-3.

Burke, M.J. and C. Stushnoff. 1979. Frost hardiness: A discussion of possible molecular causes of injury with particular reference to deep supercooling of water. In: H. Mussel and R.C. Staples (eds.). Stress physiology of crop plants. Wiley-Interscience, New York.

Burke MJ, L.V. Gusta, H.A. Quamme, C.J. Weiser, and P.H. Li 1976. Freezing injury in plants. Ann. Rev. Plant Physiol. 27:507-528.

Cai, Q., C.L. Guy, and G.A. Moore. 1994. Extension of the linkage map in Citrus using random amplified polymorphic DNA (RAPD) markers and RFLP mapping of cold-acclimation-responsive loci. Theor. Appl. Genet. 89:606-614.

Cai, Q., G.A. Moore, and C.L. Guy. 1995. An unusual group 2 LEA gene family in citrus responsive to low temperature. Plant Mol. Biol. 29:11-23.

Capel, J., J.A. Jarillo, J. Salinas, and J.M. Martinez-Zapater. 1997. Two homologous low-temperature-inducible genes from Arabidopsis encode highly hydrophobic proteins. Plant Physiol. 115:569-576.

Carter, J.R.B. and M. Wisniewski. 2001. Patterns of ice formation and movement in blackcurrant. HortScience 36:1027-1032.

Carter, J.R.B. and M. Wisniewski. 1999. Low-temperature tolerance of blackcurrant flowers. HortScience 34:855-859.

Chen, T.H.H., M.J. Burke, and L.V. Gusta. 1995. Freezing tolerance in plants: An overview. In: R.E. Lee, Jr., G.J. Warren, and L.V. Gusta (eds.). Biological ice nucleation and its applications, APS Press, Minneapolis, Minn. 
Choi, D.W., B. Zhu, and T.J. Close. 1999. The barley (Hordeum vulgare L.) dehydrin multigene family: Sequences, allele types, chromosome assignments, and expression characteristics of $11 \mathrm{Dhn}$ genes of cv. Dicktoo. Theor. Appl. Genet. 98:1234-1247.

Close, T.J. 1997. Dehydrins: A commonalty in the response of plants to dehydration and low temperature. Physiol. Plantarum 100:291-296.

Dejardin A., L.N. Sokolov, and L.A. Kleczkowski. 1999. Sugar/osmoticum levels modulate differential abscisic acid-independent expression of two stress-responsive sucrose synthase genes in Arabidopsis. Biochem. J. 344 503-509.

Dunn, M.A., M.A. Hughes, R.S. Pearce, and P.L. Jack. 1990. Molecular characterisation of a barley gene induced by cold treatment. J. Expt. Bot. 41: 1405-1413.

Dunn, M.A., M.A. Hughes, L. Zhang, R.S. Pearce, A.S. Quigley, and P.L. Jack 1991. Nucleotide sequence and molecular analysis of the low temperature induced cereal gene, BLT4. Mol. Gen. Genet. 229:389-394.

Fowler S. and M.F. Thomashow. 2002. Arabidopsis transcriptome profiling indicates that multiple regulatory pathways are activated during cold acclimation in addition to the CBF cold response pathway. Plant Cell. 14: 1675-690.

Fuchigami, L.H., D.R. Evert, and C.J. Weiser. 1970. A translocatable cold hardiness promoter. Plant Physiol. 47:164-167.

Fujikawa, S. and K. Kuroda. 2000. Cryo-scanning electron microscopic study on freezing behavior of xylem ray parenchyma cells in hardwood species. Micron 31:669-686.

Fuller, M. and M. Wisniewski. 1998. The use of infrared thermal imaging in the study of ice nucleation and freezing of plants. J. Thermal Biol. 23:81-89.

George, M.F. and M.J. Burke. 1977. Cold hardiness and deep supercooling in xylem of shagbark hickory. Plant Physiol. 59:319-325.

George, M.F., M.J. Burke, H.M., Pellet, and A.G. Johnson, 1974. Low temperature exotherms and woody plant distribution. HortScience 9:519-522.

Gilmour, S.J., N.N. Artus, and M.F. Thomashow. 1992. cDNA sequence analysis and expression of two cold-regulated genes of Arabidopsis thaliana.Plant Mol. Biol. 18:13-21.

Gilmour, S.J., A.M. Sebolt, M.P. Salazar, J.D. Everard, and M.F. Thomashow 2000. Overexpression of the Arabidopsis CBF3 transcriptional activator mimics multiple biochemical changes associated with cold acclimation. Plant Physiol. 124:1854-1865.

Gilmour S.J., D.G. Zarka, E.J. Stockinger, M.P. Salazar, J.M. Houghton, and M.F. Thomashow. 1998. Low temperature regulation of the Arabidopsis CBF family of AP2 transcriptional activators as an early step in cold-induced COR gene expression. Plant J. 16:433-442.

Goddard, N.J., M.A. Dunn, A.J.Zhang, P.L. White, P.L. Jack, and M.A. Hughes 1993. Molecular analysis and spatial expression pattern of a low-temperaturespecific barley gene, blt 101. Plant Mol. Biol. 23:871-879.

Greiner S., T. Rausch, U. Sonnewald, and K. Herbers. 1999. Ectopic expression of a tobacco invertase inhibitor homolog prevents cold-induced sweetening of potato tubers. Nat. Biotechnol. 17:708-711.

Gusta, L.V., N.J. Tyler, and T.H.H. Chen. 1983. Deep undercooling in woody taxa growing north of the $-40{ }^{\circ} \mathrm{C}$ isotherm. Plant Physiol. 72:122-128.

Guy, C. 1999. Molecular responses of plants to cold shock and cold acclimation. J. Mol. Microbiol. Biotechnol. 1:231-242.

Guy, C.L. 1990. Cold acclimation and freezing tolerance: Role of protein metabolism. Ann. Rev. Plant Physiol. Mol. Biol. 41:187-223.

Guy, C.L., J.L.A. Huber, and S.C. Huber. 1992. Sucrose phosphate synthase and sucrose accumulation at low temperature. Plant Physiol. 100:502-508.

Hirsh, A.G., R.J. Williams and H.T. Merryman. 1985. A novel method of natural cryopreservation: Intracellular glass formation in deeply frozen Populus. Plant Physiol. 79:41-56.

Hightower, R., C. Baden, E, Panzes, P. Lund, and P. Dunsmuir. 1991. Ex pression of antifreeze proteins in transgenic plants. Plant Mol. Biol. 17: 1013-1021

Holappa, L.D. and M.K. Walker-Simmons. 1995. The wheat abscisic acid-responsive protein kinase mRNA, PKABA1, is up-regulated by dehydration, cold temperature, and osmotic stress. Plant Physiol. 108:1203-1210.

Hong, S. and E. Sucoff. 1980. Units of freezing of deep supercooled water in woody xylem. Plant Physiol. 66:40-45.

Hong, S.W., J.H. Jon, J.M. Kwak, and H.G. Nam. 1997. Identification of a receptor-like protein kinase gene rapidly induced by abscisic acid, dehydration, high salt, and cold treatments in Arabidopsis thaliana. Plant Physiol. 113:1203-1212.

Horvath, D.P., B.K. McLarney, and M.F. Thomashow. 1993. Regulation of Arabidopsis thaliana L. (Heyn) cor78 in response to low temperature. Plant Physiol. 103:1047-1053.

Huang, T., J. Nicodemus, D.G. Zarka, M.F. Thomashow, M. Wisniewski, and J.G. Duman. 2002. Expression of an insect (Dendroides canadensis) antifreeze protein in Arabidopsis thaliana results in a decrease in plant freezing temperature. Plant Mol. Biol. 50:333-344.
Irving, R.M. and F.O. Lanphear. 1967. The long day leaf as a source of cold hardiness inhibitors. Plant Physiol. 42:1191-1196.

Jaglo-Ottosen, K.R., S.J. Gilmour, D.G. Zarka, O. Schabenberger, and M.F. Thomashow. 1998. Arabidopsis CBF1 overexpression induces COR genes and enhances freezing tolerance. Science. 280:104-106.

Jonak, C., S. Kiegerl, W. Ligterink, P.J. Barker, N.S. Huskisson, and H Hirt. 1996. Stress signaling in plants: a mitogen-activated protein kinase pathway is activated by cold and drought. Proc. Natl. Acad. Sci. USA 93: 11274-11279.

Juntilla, O., A. Welling, C. Li, B.A. Tsegay, and E.T. Palva. 2002. Physiological aspects of cold hardiness in northern deciduous tree species. In: P.H. $\mathrm{Li}$ and E.T. Palva (eds.). Plant cold hardiness. Gene regulation and genetic engineering. Kluwer Academic/Plenum Publ., New York.

Kasuga, M., O. Liu, M. Setsuko, K. Yamaguchi-Shinozaki, and K. Shinozaki. 1999. Improving plant drought, salt, and freezing tolerance by gene transfer of a single stress-inducible transcription factor. Nat. Biotechnol. 17: 287-291.

Kaye, C. and C.L. Guy. 1995. Perspectives of plant cold tolerance: physiology and molecular responses. Sci. Prog. 78:271-299.

Kaye, C., L. Neven, A. Hofig, Q.B. Li, D. Haskell, and C. Guy. 1998. Characterization of a gene for spinach CAP160 and expression of two spinach cold-acclimated proteins in tobacco. Plant Physiol. 116:1367-1377.

Kim, K.M., J.K. Sohn, and I.K. Chung. 2000. Analysis of OPT8511 RAPD fragments closely linked with cold sensitivity at the seedling stage in rice (Oryza sativa L.). Mol. Cells 10:382-385.

Knight, K. and M.R. Knight. 2001. Abiotic stress signalling pathways: Specificity and cross-talk. Trends Plant Sci. 6:262-267.

Knight, H., E.L. Veale, G.J. Warren, and M.R. Knight. 1999. The sfr6 mutation in Arabidopsis suppresses low-temperature induction of genes dependent on the CRT/DRE sequence motif. Plant Cell 11:875-886.

Kollipara, K.P., I.N. Saab, R.D. Wych, M.J. Lauer, and G.W. Singletary. 2002. Expression profiling of reciprocal maize hybrids divergent for cold germination and desiccation tolerance. Plant Physiol. 129:974-992.

Kurkela, S. and M. Franck. 1990. Cloning and characterization of a cold- and ABA-inducible Arabidopsis gene. Plant Mol. Biol. 15:137-144.

Kuroda, K., J. Kasuga, K. Arakawa, and S. Fujikawa. 2003. Xylem ray parenchyma cells in boreal hardwood species respond to subfreezing termperatures by deep supercooling that is accompanied by incomplete desiccation. Plant Physiol. 131:736-744.

Laberge, S., Y. Castonguay, and L.P. Vézina. 1993. New cold- and droughtregulated gene from Medicago sativa. Plant Physiol. 101:1411-1412.

Lee, H., L. Xiong, Z. Gong, M. Ishitani, B. Stevenson, and J.-K.Zhu. 2001. The Arabidopsis HOS1 gene negatively regulates cold signal transduction and encodes a RING finger protein that displays cold-regulated nucleocytoplasmic partitioning. Genes Dev. 15:912-924.

Lee, H., Y. Guo, M. Ohta, L. Xiong, B. Stevenson, and J.-K. Zhu. 2002. LOS2, a genetic locus required for cold-responsive gene transcription encodes a bi-functional enolase. EMBO J. 21:2692-2702.

Lee, R.E., Jr., G.J. Warren, and L.V. Gusta. 1995. Biological ice nucleation and its applications. APS Press, Minneapolis, Minn.

Levi, A., G.R. Panta, C.M. Parmentier, M.M. Muthalif, R. Arora, S. Shanker, and L.J. Rowland. 1999. Complementary DNA cloning, sequencing and expression of an unusual dehydrin from blueberry floral buds. Physiol. Plantarum 107:98-109.

Levitt, J. 1980. Response of plant to environmental stresses. 2nd ed. I. Chilling, freezing, and high temperature stresses. Academic Press, New York.

Levitt, J. 1972. Response of plants to environmental stress. Academic Press, New York.

Levitt, J. and G.W. Scarth. 1936a. Frost hardening studies with living cells I. Osmotic and bound water changes in relation frost resistance and the seasonal cycle. Can J. Res. Sect. C. 14:267-284.

Levitt, J. and G.W. Scarth. 1936b. Frost hardening studies with living cells. II. Permeability in relation to frost resistance and the seasonal cycle. J. For. Res. Sect. C. 14:285-305.

Levitt, J. and D. Siminovitch. 1940. The relation between frost resistance and the physical state of the protoplasm. I. The protoplasm as a whole. Can. J. Res. Sect. C. 18:550-561.

Lindow SE. 1995. Control of epiphytic ice-nucleation-active bacteria for management of plant frost injury. In: Lee R.E., Jr, G.J. Warren and L.V. Gusta (eds.). Biological ice nucleation and its applications. APS Press, St. Paul, Minn.

Liu, O., M. Kasuga, Y. Sakuma, H. Abe, S. Miura, K. Yamaguchi-Shinozaki, and K. Shinozaki. 1998. Two transcription factors, DREB1 and DREB2, with an EREBP/AP2 DNA binding domain separate two cellular signal transduction pathways in drought- and low-temperature-response gene expression, respectively, in Arabidopsis. Plant Cell 10:1391-1406.

Llorente, F., R.M. Lopez-Cobollo, R. Catala, J.M. Martinez-Zapater, and J. Salinas. 2002. A novel cold-inducible gene from Arabidopsis, RCI3, 
encodes a peroxidase that constitutes a component for stress tolerance. Plant J. 32:13-24.

Llorente, F., J.C. Oliveros, J.M. Martinez-Zapater, and J. Salinas. 2000. A freezing-sensitive mutant of Arabidopsis, frs 1, is a new aba3 allele. Planta. 211:648-655.

Luo, M., L.H. Lin, R.D. Hill, and S.S. Mohapatra. 1991. Primary structure of an environmental stress and abscisic acid-inducible alfalfa protein. Plant Mol. Biol. 17:1267-1269.

Luo, M., J.H.Liu, S. Mohapatra, R.D. Hill, and S.S. Mohapatra. 1992. Characterization of a gene family encoding abscisic acid- and environmental stress-inducible proteins of alfalfa. J. Biol. Chem. 267:15367-15374.

Lynch, D.V. and P.L. Steponkus. 1987. Plasma membrane lipid alterations associated with cold acclimation of winter rye seedlings (Secale cereale $\mathrm{L}$. cv. Puma). Plant Physiol. 83:761-767.

Maximov, N.A. 1912. Chemische schutzmittel der Pflanzen gegen erfrieren. Ber. Dtsch. Bot. Ges. 30:52-65.

Medina, J., M. Bargues, J. Terol, M. Perez-Alonso, and J. Salinas. 1999. The Arabidopsis $C B F$ gene family is composed of three genes encoding AP2 domain-containing proteins whose expression is regulated by low temperature but not by abscisic acid or dehydration. Plant Physiol. 119:463-470.

Meskiene, I., L. Bogre, W. Glaser, J. Balog, M. Brandstotter, K. Zwerger, G. Ammerer, and H. Hirt. 1998. MP2C, a plant protein phosphatase 2C, functions as a negative regulator of mitogen-activated protein kinase pathways in yeast and plants. Proc. Natl. Acad. Sci. USA 95:1938-1943.

Molisch, H. 1897. Untersuchungen über das erfrieren der Pflanzen (reprinted in English 1982) Cryo-Lett. 3:332-390.

Monroy, A.F., Y. Castonguay, S. Laberge, F. Sarhan, L.P. Vezina, and R.S Dhindsa. 1993. A new cold-induced alfalfa gene is associated with enhanced hardening at subzero temperature. Plant Physiol. 102:873-879.

Monroy, A.F. and R.S. Dhindsa. 1995. Low-temperature signal transduction: Induction of cold acclimation-specific genes of alfalfa by calcium at 25 degrees C. Plant Cell. 7:321-331.

Muthalif, M.M. and L.J. Rowland. 1994. Identification of dehydrin-like proteins responsive to chilling in floral buds of blueberry (Vacciniium, section Cyanococcus). Plant Physiol. 104:1439-1447.

Ndong, C., J. Danyluk, K.E. Wilson, T. Pocock, N.P. Huner, and F. Sarhan 2002. Cold-regulated cereal chloroplast late embryogenesis abundant-like proteins. Molecular characterization and functional analyses. Plant Physiol. 129:1368-1381

Newton, S.S. and J.G. Duman. 2000. An osmotin-like cryoprotective protein from the bittersweet nightshade Solanum dulcamara. Plant Mol. Biol. 44: 581-589.

Orr,W., B. Iu, T. White, L.S. Robert, and J. Singh. 1992. Nucleotide sequence of a winter B. napus Kin 1 cDNA. Plant Physiol. 98:1532-1534.

Orr,W., T.C. White, B. Iu, L. Robert, and J. Singh. 1995. Characterization of a low-temperature-induced cDNA from winter Brassica napus encoding the 70 kDa subunit of tonoplast ATPase. Plant Mol. Biol. 28:943-948.

Palta, J.P. and P.H. Li. 1978. Cell membrane properties in relation to freezing injury. In. P.H. Li and H. Sakai (eds.). Plant cold hardiness and freezing stress. Academic Press, New York.

Palta, J.P. and P.H. Li. 1980. Alterations in membrane transport properties by freezing injury in herbaceous plants: Evidence against the rupture theory. Physiol. Plant. 50:169-175.

Pearce, R.S. and M.P. Fuller. 2001. Freezing of barley studied by infrared video thermography. Plant Physiol. 125:227-240.

Pomeroy, M.K. and D. Siminovitch. 1971. Seasonal cytological changes in secondary phloem parenchyma cells in Robinia pseudoacacia in relation to cold hardiness. Can. J. Bot. 49:787-795.

Quamme, H. 1995. Deep supercooling in buds of woody plants. In: R.E. Lee, Jr., G.J. Warren, and L.V. Gusta (eds.). Biological ice nucleation and its applications. APS Press, St. Paul, Minn.

Quamme, H.A., W.A. Su, and L.J. Veto. 1995. Anatomical features facilitating supercooling of the flower within the dormant peach bud. J. Amer. Soc. Hort. Sci. 12:814-822.

QuammeH.A., C.Stushnoff, and C.J. Weiser. 1972. The relationship of exotherms to cold injury in apple stem tissues. J. Amer. Soc. Hort. Sci. 97:608-613.

Quamme, H.A., C.J. Weiser, and C.Stushnoff. 1973. The mechanism of freezing injury in xylem of winter apple twigs. Plant Physiol. 51:273-277.

Rinne, P., A. Welling, and P. Kaikuranta. 1998. Onset of freezing tolerance in birch (Betula pubescens) involves LEA proteins and osmoregulation and is impaired in an ABA-deficient genotype. Plant Cell Environ. 21:601-611.

Rinne, P., P. Kaikuranta, L.H. van der Plas, and C. van der Schoot. 1999. Dehydrins in cold-acclimated apices of birch: production, localization and potential role in rescuing enzyme function during dehydration. Planta 209: 377-388.

Ristic, Z. and E.N. Ashworth. 1993. Ultrastructural evidence that intracellular ice formation and possibly cavitation are the sources of freezing injury in supercooled wood tissue of Cornus florida L. Plant Physiol. 103:753-761.
Ristic, Z. and E.N. Ashworth. 1994. Responce of xylem ray parenchyma cells of red osier dogwood (Cornus sericea L.) to freezing stress: Microscopic evidence of protoplasm contraction. Plant Physiol. 104:737-746.

Roberts, D.W.A. and J.P. Miska. 1980. Cold hardiness and winter survival of plants: 1965-1975. Commonwealth Bur. Soils Spec. Publ. No. 8. Commonwealth Agr. Bur., London.

Ruelland, E., C. Cantrel, M. Gawer, J.C. Kader, and A. Zachowski. 2002. Activation of phospholipases $\mathrm{C}$ and $\mathrm{D}$ is an early response to a cold exposure in Arabidopsis suspension cells. Plant Physiol. 130:999-1007.

Saez-Vasquez, J., M. Raynal, and M. Delseny. 1995. A rapeseed cold-inducible transcript encodes a phosphoenolpyruvate carboxykinase. Plant Physiol. 109:611-618.

Sakai, A. and W. Larcher. 1987. Frost survival of plants. Springer, Berlin.

Sangwan, V. and R.S. Dhindsa. 2002. In vivo and in vitro activation of temperature-responsive plant map kinases. FEBS Lett. 531:561-564.

Sarnighausen, E., D. Karlson, and E. Ashworth. 2002. Seasonal regulation of a 24-kDa protein from red-osier dogwood (Cornus sericea) xylem. Tree Physiol. 22:423-430.

Scarth, G.W. and J. Levitt. 1937. The frost hardening mechanism of plant cells. Plant Physiol. 12:51-78.

Seppanen, M.M., T. Cardi, M. Borg Hyokki, and E. Pehu. 2000. Characterization and expression of cold-induced glutathione S-transferase in freezing tolerant Solanum commersonii, sensitive $S$. tuberosum and their interspecific somatic hybrids. Plant Sci. 153:125-133.

Shinozaki, K. and K. Yamaguchi-Shinozaki. 2000. Molecular responses to dehydration and low temperature: differences and cross-talk between two stress signaling pathways. Curr. Opin. Biotechnol. 3:217-223.

Siminovitch, D. and J. Levitt. 1941. The relation between frost resistance and the physical state of the protoplasm. II. The protoplasmic surface. Can. J. Res. Sect. C. 19:9-20.

Siminovitch, D. and G.W. Scarth. 1938. A study of the mechanism of frost injury to plants. Can. J. Res. Sect. C. 16:467-481.

Siminovitch, D., J. Singh, and I.A. de la Roche. 1975. Studies on membranes in plant cells resistant to extreme freezing. I. Augmentation of phospholipids and membrane substance without changes in unsaturation of fatty acids during hardening of black locust bark. Cryobiology 12:144-153.

Steponkus, P.L. 1984. Role of the plasma membrane in freezing injury and cold acclimation. Ann. Rev. Plant Physiol. 35:543-583.

Steponkus, P.L., R. Lang, and S. Fujikawa. 1992. Cryopreservation of plant tissues by vitrifications. In: P.L. Steponkus (ed.). Advances in low-temperature biology. JAI Press, Ltd., London.

Steponkus, P.L., M. Uemura, R.A. Joseph, S.J. Gilmour, and M.F. Thomashow. 1998. Mode of action of the COR15a gene on the freezing tolerance of Arabidopsis thaliana. Proc. Natl. Acad. Sci. USA 95:14570-14575.

Sutinen, M-J., Arora, R., M. Wisniewski, E. Ashworth, R. Strimbeck, and J. Palta. 2001. Mechanisms of frost survival and freeze-damage in nature. In: F.J. Bigras and S.J. Colombo (eds.). Conifer cold hardiness. Kluwer Academic Publ., Dordrecht. The Netherlands.

Tafforeau, M., M.C. Verdus, R. Charlionet, A. Cabin-Flaman, and C. Ripoll. 2002. Two-dimensional electrophoresis investigation of short-term response of flax seedlings to a cold shock. Electrophoresis 23:2534-2540.

Tahtiharju, S. and T. Palva. 2001. Antisense inhibition of protein phosphatase $2 \mathrm{C}$ accelerates cold acclimation in Arabidopsis thaliana. Plant J. 26: 461-470.

Taji, T., C. Ohsumi, S. Iuchi, M. Seki, M. Kasuga, M. Kobayashi, K. Yamaguchi-Shinozaki, and K. Shinozaki. 2002. Important roles of drought- and cold-inducible genes for galactinol synthase in stress tolerance in Arabidopsis thaliana. Plant J. 29:417-426.

Tamminen, I., P. Makela, P. Heino, and E.T. Palva ET. 2001. Ectopic expression of ABI3 gene enhances freezing tolerance in response to abscisic acid and low temperature in Arabidopsis thaliana. Plant J. 25:1-8.

Thomashow, M.F. 1998. Role of cold-responsive genes in plant freezing tolerance. Plant Physiol. 118:1-8.

Thomashow, M.F. 1999. Plant cold acclimation: Freezing tolerance genes and regulatory mechanisms. Annu. Rev. Plant Physiol. Plant Mol. Biol. 50: 571-599.

Thomashow, M. 2001. So what's new in the field of plant cold acclimation? Lots! Plant Physiol. 125:89-93.

Tumanov, I.I. and O.A. Krasavtsev. 1962. Hardening of northern woody plants by temperatures below zero. Sov. Plant Physiol. 9:474-482.

Tumanov, I.I., O.A. Krasavtsev and T. I. Trunova. 1969. Investigation fo the ice formation processes in plants by measuring heat evolution. Sov. Plant Physiol. 17:754-760.

Tsuda, K., S. Tsvetanov, S. Takumi, N. Mori, A. Atanassov and C. Nakamura. 2000. New members of a cold-responsive group-3 Lea/Rab-related Cor gene family from common wheat (Triticum aestivum L.). Genes Genet. Syst. 75:179-188.

Ukaji, N., C. Kuwabara, D. Takezawa, K. Arakawa, S. Yoshida and S. Fujikawa. 
1999. Accumulation of small heat-shock protein homologs in the endoplasmic reticulum of cortical parenchyma cells in mulberry in association with seasonal cold acclimation. Plant Physiol. 120:481-490.

Ukaji, N., C. Kuwabara, D. Takezawa, K. Arakawa and S. Fujikawa. 2001 Cold acclimation-induced WAP27 localized in endoplasmic reticulum in cortical parenchyma cells of mulberry tree was homologous to group 3 lateembryogenesis abundant proteins. Plant Physiol. 126:1588-1597.

Weiser, C.J. 1970. Cold resistance and injury in woody plants. Science 169: 1269-1278.

Welin, B.V., A. Olson, M. Nylander and E.T. Palva. 1994. Characterization and differential expression of dhn/lea/rab-like genes during cold acclimation and drought stress in Arabidopsis thaliana. Plant Mol. Biol. 26:131-144.

Welling, A., P. Kaikuranta, and P. Rinne. 1997. Photoperiodic induction of dormancy and freezing tolerance in Betula pubescens: Involvement of ABA and dehydrins. Physiol Plant. 100:119-125.

Weretilnyk, E., W. Orr, T.C. White, B. Iu, and J. Singh. 1993. Characterization of three related low-temperature-regulated cDNAs from winter Brassica napus. Plant Physiol. 101:171-177.

Wiegand, K.M. 1906. The occurrence of ice in plant tissue. Plant World 9: 25-39.

Wisniewski, M. 1995. Deep supercooling in woody plants and the role of cell wall structure. In: R.E. Lee, Jr., G.J. Warren, and L.V. Gusta (eds.). Biological ice nucleation and its applications. APS Press, Minneapolis, Minn.

Wisniewski, M. and R. Arora. 1993. Adaptation and response of fruit trees to freezing temperatures. In: A.R. Biggs (ed.). Cytology, histology, and histochemistry of fruit tree diseases. CRC Press, Boca Raton, Fla.

Wisniewski, M. and R. Arora. 2000. Structural and biochemical aspects of cold hardiness in woody plants. In: S.M. Jain and S.C. Minocha (eds.). Molecular biology of woody plants. vol. 2. Kluwer Academic Publ., Dordrecht, The Netherlands.

Wisniewski, M. and G. Davis. 1989. Evidence for the involvement of a specific cell wall layer in the regulation of deep supercooling of xlem parenchyma. Plant Phsyiol. 139:105-116.

Wisniewski, M. and G. Davis. 1995. Immunogold localization of pectins and glycoproteins in tissues of peach with reference to deep supercooling. Trees 9:253-260.

Wisniewski, M. and M. Fuller. 1999. Ice nucleation and deep supercooling plants: New insights using infrared thermography. In: R. Margesin and F. Schinner(eds.). Cold adapted organisms: Ecology, physiology, enzymology, and molecular biolgy. Springer-Verlag, Berlin.

Wisniewski, M., G. Davis, and R. Arora. 1991a. Effect of macerase, oxalic acid, and EGTA on deep supercooling and pit membrane structure of xylem parenchyma of peach. Plant Physiol. 139:1354-1359.

Wisniewski, M., G. Davis, and K. Schaffer. 1991b. Mediation of deep supercooling of peach and dogwood by enzymatic modifications in cell-wall structure. Planta 184:254-260.

Wisniewski, M., D.M. Glenn, and M. Fuller. 2002. Use of a hydrophobic particle film as a barrier to extrinsic ice nucleation in tomato plants. J. Amer. Soc. Hort. Sci. 127:358-364.

Wisniewski, M., S.E. Lindow, and E.N. Ashworth. 1997. Observations of ice nucleation and propagation in plants using infrared thermography. Plant Physiol. 113:327-334.

Wisniewski, M., M. Fuller, D.M. Glenn, L.V. Gusta, J. Duman, and M. Griffith 2002b. Extrinsic ice nucleation in plants: What are the factors and can they be manipulated. In: P.H. Li and E.T. Palva (eds.). Plant cold hardiness: Gene regulation and genetic engineering. Kluwer Academic/Plenum Publ, New York.

Workmaster, B.A., J.P. Palta, and M. Wisniewski. 1999. Ice nucleation and propagation in cranberry uprights and fruit using infrared video thermography. J. Amer. Soc. Hort. Sci. 124:619-625.

Wu, Y., J. Kuzma, E. Marechal, R. Graeff, H.C. Lee, R. Foster, and N.H. Chua. 1997. Abscisic acid signaling through cyclic ADP-ribose in plants. Science 278:2126-2130

Xin, Z. and J. Browse. 1998. eskimo1 mutants of Arabdopsis are constitutively freezing-tolerant. Proc. Natl. Acad. Sci. USA 95:7799-7804.

Xin, Z. and J. Browse. 2000. Cold comfort farm: the acclimation of plants to freezing temperatures. Plant Cell Environ. 23:893-902.

Xing, W. and C.B. Rajashekar. 2001. Glycine betaine involvement in freezing tolerance and water stress in Arabidopsis thaliana.Environ. Expt. Bot. 46: 21-28.

Xiong, L., H. Lee, M. Ishitani, Y. Tanaka, B. Stevenson, H. Koiwa, R.A. Bressan, P.M. Hasegawa, and J.K. Zhu. 2002a. Repression of stress-responsive genes by FIERY2, a novel transcriptional regulator in Arabidopsis. Proc. Natl. Acad. Sci. USA 99:10899-10904.

Xiong, L., K.S. Schumaker, and J.K. Zhu. 2002b. Cell signaling during cold, drought, and salt stress. Plant Cell 14 Suppl:S165-183.

Yamaguchi-Shinozaki, K. and K. Shinozaki. 1994. A novel cis-acting element in an Arabidopsis gene is involved in responsiveness to drought, low-temperature, or high-salt stress. Plant Cell 6:251-264.

Yeh, S., B.A. Moffatt, M. Griffith, F. Xiong, D.S. Yang, S.B. Wiseman, F. Sarhan, J. Danyluk, Y.Q. Xue, C.L. Hew, A. Doherty-Kirby, and G. Lajoie. 2000. Chitinase genes responsive to cold encode antifreeze proteins in winter cereals. Plant Physiol. 124:1251-1264. 